\title{
Effect of B1 and B12 vitamins injection on milk yield, composition and some blood biochemical in Holstein dairy cows
}

\author{
Ehsan Mohseni and Amir Davar Foroozandeh* \\ Department of Animal Sciences, Khorasgan (Isfahan) Branch, Islamic Azad University, Isfahan, Iran
}

\begin{tabular}{|l|l|}
\hline Article history & Abstract \\
Received: 13 Feb, 2016 & This study was performed to determine the effect of B1 and B12 vitamin injection on \\
Revised: 7 April, 2016 & milk production, milk composition and some blood biochemical in Holstein dairy \\
Accepted: 21 April, 2016 & $\begin{array}{l}\text { cows. A total } 40 \text { Holstein dairy cows with average milk production } 30 \pm 50 \mathrm{~kg} \text {, initial } \\
\text { weight } 600 \pm 50 \mathrm{~kg} \text { and } 28 \text { days after calving were evaluated. The treatments were } \\
\text { control diet, and intramuscular injection of } 15 \mathrm{IU} \text { vitamin B1, 10 IU vitamin B12 or } \\
\text { combination of vitamin B1 and B12 on a weekly basis. Milk production and its } \\
\text { composition were measured after 4, 6, 8 and } 14 \text { week. Data from this study showed } \\
\text { that although milk production was not influenced significantly The results of the study } \\
\text { indicated that milk protein was increased significantly in B1 and B2 treated groups } \\
\text { while milk lactose decreased significantly in B1. Total protein increased significantly } \\
\text { in B1 while cholesterol and triglyceride increased significantly in B12 in lactating } \\
\text { cows. The results indicated that treatment of vitamin B1 and B12 impacted milk } \\
\text { composition and blood biochemical profile in lactating Holstein cows. } \\
\text { Keywords: } \mathrm{B}_{1} \text { and B } \mathrm{B}_{12} \text { vitamins; milk; lactose; blood biochemistry; Holstein dairy cows }\end{array}$ \\
\hline
\end{tabular}

\footnotetext{
To cite this article: Mohseni $\mathrm{E}$ and $\mathrm{AD}$ Foroozandeh, 2016. Effect of B1 and B12 vitamins injection on milk yield, composition and some blood biochemical in Holstein dairy cows. Res. Opin. Anim. Vet. Sci., 6(4): 126129.
}

\section{Introduction}

Vitamin B complex helps the body to convert carbohydrates into glucose, which is used to produce energy. These vitamins also help the body to metabolize fats and protein. B complex vitamins are needed for healthy skin, hair, eyes, and liver. They also help the nervous system function properly, and are needed for good brain function. Thiamine (B1) is sometimes called an "anti-stress" vitamin because it may strengthen the immune system and improve the body's ability to withstand stressful conditions. Thiamine is found in both plants and animals and plays a critical role in certain metabolic reactions. The body needs it to form adenosine tri phosphate (ATP). It is generally accepted that B-vitamins requirements can be met through synthesis by ruminal bacteria and dietary sources that escape from the rumen (National Research Council, 2001). Consequently, very little research effort has been directed at defining dairy cow requirements for B vitamins. Over the past 50 years, however, milk and milk component yields have increased dramatically. It is likely that the B-vitamins requirements of high-producing dairy cows have likewise increased and that ruminal synthesis alone is not sufficient to meet these new needs. Moreover, vitamin B1 is necessary for healthy mucous membranes, helps in the digestion of food, provides strength to muscles and very useful for the proper functioning of the heart (McDowell, 2000). This

*Corresponding author: Davar Foroozandeh, Amir Davar Foroozandeh, Department of Animal Sciences, Khorasgan (Isfahan) Branch, Islamic Azad University, Isfahan, Iran 
hypothesis is supported by studies that have reported beneficial effects of supplementation with thiamin (Shaver and Bal, 2000). Vitamin B12, also called cobalamin, is a water soluble vitamin with a key role in the normal functioning of the brain and nervous system, and for the formation of blood. Vitamin B12 is consisting of a class of chemically related compounds, all of which have vitamin activity. The high-producing dairy cow requires a large supply of energy and glucose. Huge amounts of glucose are required by the lactating mammary gland to synthesize lactose, the primary osmotic controller of milk volume (Overton, 1998). A cow producing $40 \mathrm{~kg}$ of milk per day requires approximately $3 \mathrm{~kg}$ of glucose per day (Girard et al., 1995). A lack of vitamin B12 in early lactation could reduce utilization of supplementary folic acid by the cow's tissues, given that folic acid becomes "trapped" in the serum under its methylated form, 5-methyltetrahydrofolate. In fact, a lack of vitamin B12 inhibits methionine and S-adenosylmethionine synthesis. All available one-carbon units are diverted to the synthesis of 5-methyl-tetrahydrofolate. This reaction is irreversible, and demethylation through the regeneration of mthionine is blocked by the lack of vitamin B12.

Research on these micronutrients is still in its infancy, so this study was performed to determine the effect of $\mathrm{B} 1$ and $\mathrm{B} 12$ vitamin injection on milk production, milk composition and some blood biochemical in Holstein dairy cows.

\section{Materials and Methods}

This study was carried out in cooperating Vahdat Agricultural and Livestock Cooperative Company, Isfahan, Iran.

\section{Experimental animals}

Forty multiparous (2-5) lactating Holstein dairy cow were assigned randomly into four experimental treatments. Dairy cows weighed an average of $600 \pm 0.50 \mathrm{~kg}$, with average $30 \pm 0.5 \mathrm{~kg}$ milk production daily were divided into a control (basal diet) and intramuscular injection of 15 IU vitamin B1, 10 IU vitamin B12 and a combination of vitamin B1 and B12. Feed and fresh water were provided ad libitum during the experimental period. The control diet was corn silage, wheat straw, barely, molasses, soybean meal and minerals as shown in Table 1 . The animals received their requirements according to NRC (2001).

Cows were milked three times a day at 6.00, 14.00 and 22.00. This procedure was repeated weekly during the whole suckling periods. Milk samples $(70 \mathrm{ml})$ were taken for chemical analysis and stored at $4{ }^{\circ} \mathrm{C}$ for determination of fat, protein and lactose content (Milkoscan device (MilkoScan ${ }^{\mathrm{TM}}$ FT2).
Blood samples from each animal in different treatments were taken after morning feeding from tail vein and collected at the beginning of the experiment up to 14 weeks. Blood samples were allowed to clot at $4^{\circ} \mathrm{C}$ temperature and serum was then separated by centrifugation at $1850 \mathrm{rpm}$ for 20 minutes. Serum samples were divided into two parts and then transferred into dry glass vials and stored at $-20^{\circ} \mathrm{C}$ until subsequent analysis. Serum samples were analyzed using Pars Azmoon ${ }^{\circledR}$ kits and Auto Analyzer (Technico R.A 1000).

\section{Statistical Analysis}

Data were analyzed by using the general linear model procedure of SAS (2001). Means were separated by Duncan's multiple range test to detect the significant difference $(\mathrm{P}<0.05)$

The used statistical analysis in this trial was as below:

$Y i j=\mu+T i+e i j$

Whereas: $\mathrm{Yij}=$ Dependent variable, $\mu=$ Total average, $\mathrm{Ti}=$ Treatments, eij $=$ Remained effects

\section{Results}

The presented results in Table 2 indicate that the milk yield was decreased by using B1 and B12 vitamins with no significant effect between the treatments.

The presented results in Table 3 indicate that milk protein percentage was increased none significantly by using $\mathrm{B} 1$ and $\mathrm{B} 12$ vitamin injection. Milk protein improved as a result of B1 and B12 vitamins. Data in Table 4 illustrated that total milk fat were $2.65,2.49$ and $2.69 \%$ for $\mathrm{B} 1, \mathrm{~B} 12$ and $\mathrm{B} 1+\mathrm{B} 12$ respectively compared with control (2.46). Milk fat percentage improved as a result of B1 and B12 Injection. Data in Table 5 showed significant differences in milk lactose at the sixth week of the experimental plan. Significantly $(\mathrm{P}<0.05)$ low milk lactose was found in cows treated with $\mathrm{B} 1$. The presented results in Table 6 indicated that serum protein increased significantly $(\mathrm{P}<0.05)$ in $\mathrm{B} 1$ while cholesterol and triglyceride increased significantly $(\mathrm{P}<0.05)$ in $\mathrm{B} 12$.

\section{Discussion}

The presented results of this study showed that milk yield decreased in combined treatment of B1 and B12 injection, but milk fat and milk protein percentage tended to increase. Solouma et al. (2014) showed that protein improved as a result of thiamine effect and milk production improved as a result of enhanced blood total protein in comparison with control. Majee et al. ( 2003) indicated that milk production was increased when cows were fed a mixture of B-vitamins (biotin, folic 
Res. Opin. Anim. Vet. Sci., 2016, 6(4): 126-129.

Table 1: The composition of basal diets (dry matter basis)

\begin{tabular}{lc}
\hline Composition (kg/d) & \\
\hline Alfalfa hay & 4 \\
Corn silage & 5 \\
Concentrate composition (\%) & \\
Cotton seed & 5.78 \\
Corn glutton & 2.75 \\
Barley & 15.30 \\
corn & 36.72 \\
Fat powder & 3.67 \\
Fish meal powder & 4.01 \\
Canola meal & 6.12 \\
Soybean meal & 19.09 \\
Calcium carbonate & 1.76 \\
Dicalcium phosphate & 0.49 \\
Sodium chloride & 0.69 \\
Sodium Bicarbonate & 1.57 \\
Minerals & 0.69 \\
Vitamin premix $\left(\mathrm{A}, \mathrm{D}_{3}, \mathrm{E}\right)$ & 0.69 \\
Magnesium oxide & 0.29 \\
Toxin binder & 0.39 \\
\hline
\end{tabular}

Table 2: Effect of vitamin B1 and B12 injection on milk yield $(\mathrm{kg} / \mathrm{d})$

\begin{tabular}{lccccc}
\hline Experimental & \multicolumn{5}{c}{ Treatments } \\
\cline { 2 - 6 } period (week) & Control & B1 & B12 & B1+B12 & SEM \\
\hline 6 & 41.8 & 39.2 & 39.8 & 37.5 & 1.73 \\
8 & 41.2 & 38.1 & 39.7 & 38.8 & 2.10 \\
14 & 39.4 & 37.0 & 39.2 & 38.7 & 1.87 \\
Total & 40.6 & 38.2 & 39.4 & 37.4 & 1.59
\end{tabular}

Means within row with no common on letter are significantly different $(\mathrm{P}<0.05)$.

Table 3: Effect of vitamin $B_{1}$ and $B_{12}$ injection on milk Protein (\%)

\begin{tabular}{lccccc}
\hline Experimental & \multicolumn{5}{c}{ Treatments } \\
\cline { 2 - 6 } period (week) & Control & B1 & B12 & B1+B12 & SEM \\
\hline 6 & $2.74^{\mathrm{ab}}$ & $2.75^{\mathrm{ab}}$ & $2.81^{\mathrm{a}}$ & $2.70^{\mathrm{a}}$ & 0.032 \\
8 & 2.93 & 2.94 & 2.95 & 2.87 & 0.051 \\
14 & 2.93 & 2.96 & 2.99 & 3.01 & 0.075 \\
Total & 2.87 & 2.88 & 2.91 & 2.87 & 0.046 \\
\hline
\end{tabular}

Means within row with no common on letter are significantly different $(\mathrm{P}<0.05)$.

acid, niacin, pantothenic acid, B-6, riboflavin, thiamin, and B12) compared with cows not fed supplemental Bvitamins but was not different from a treatment in which only biotin was supplemented. The improvement in the milk yield performance as a result of increased total protein in blood may be due to the positive effect of these treatments on the digestibility coefficient of different nutrients and nutritive values as suggested by Farahat et al. (2007). The results of this study indicate that there is an increase in the metabolism and decrease in the catabolism as a result of improved total protein in blood. Increased metabolism and decreased catabolism may lead to improved milk yield. These results are in agreement with the findings of Sapienza (1981). It has been suggested that levels of water soluble B vitamins may be insufficient to meet the needs of dairy cows
Table 4: Effect of vitamin $B_{1}$ and $B_{12}$ injection on milk fat (\%)

\begin{tabular}{lccccc}
\hline \multirow{2}{*}{$\begin{array}{l}\text { Experimental } \\
\text { period (week) }\end{array}$} & \multicolumn{5}{c}{ Treatments } \\
\cline { 2 - 6 } & Control & B1 & B12 & B1+B12 & SEM \\
\hline 6 & 2.73 & 2.93 & 2.57 & 2.92 & 0.18 \\
8 & 2.28 & 2.35 & 2.31 & 2.72 & 0.19 \\
14 & 2.37 & 2.67 & 2.62 & 2.30 & 0.19 \\
Total & 2.46 & 2.65 & 2.49 & 2.69 & 0.13 \\
\hline
\end{tabular}

Means within row with no common on letter are significantly different $(\mathrm{P}<0.05)$.

Table 5: Effect of vitamin $B_{1}$ and $B_{12}$ injection on milk lactose (\%)

\begin{tabular}{lccccc}
\hline Experimental & \multicolumn{5}{c}{ Treatments } \\
\cline { 2 - 6 } period (week) & Control & $\mathrm{B}_{1}$ & $\mathrm{~B}_{12}$ & $\mathrm{~B}_{1}+\mathrm{B}_{12}$ & $\mathrm{SEM}$ \\
\hline 6 & $4.79^{\mathrm{a}}$ & $4.65^{\mathrm{b}}$ & $4.76^{\mathrm{ab}}$ & $4.68^{\mathrm{ab}}$ & 0.06 \\
8 & 4.73 & 4.69 & 4.77 & 4.70 & 0.053 \\
14 & 4.76 & 4.66 & 4.75 & 4.67 & 0.062 \\
Total & 4.76 & 4.66 & 4.76 & 4.68 & 0.049 \\
\hline
\end{tabular}

Means within row with no common on letter are significantly different $(\mathrm{P}<0.05)$.

Table 6: Effect of vitamin $B_{1}$ and $B_{12}$ injection on some blood biochemical parameters

\begin{tabular}{llllll}
\hline Blood samples & \multicolumn{7}{c}{ Treatments } \\
\cline { 2 - 6 } & Control & B1 & B12 & B1+B12 & SEM \\
\hline
\end{tabular}

\begin{tabular}{llllll}
\hline Total Protein $(\mathrm{mg} / \mathrm{dl})$ & $7.45^{\mathrm{b}}$ & $8.15^{\mathrm{a}}$ & $7.56^{\mathrm{b}}$ & $7.57^{\mathrm{b}}$ & 0.19
\end{tabular}

$\begin{array}{llllll}\text { Cholesterol (mg/dl) } & 298.8^{\mathrm{ab}} & 258^{\mathrm{b}} & 302.6^{\mathrm{a}} & 266.3^{\mathrm{ab}} & 15.8\end{array}$

\begin{tabular}{llllll} 
Triglyceride $(\mathrm{mg} / \mathrm{dl})$ & $14.4^{\mathrm{a}}$ & $12.1^{\mathrm{b}}$ & $15.4^{\mathrm{a}}$ & $13.5^{\mathrm{ab}}$ & 0.83 \\
\hline
\end{tabular}

*Means within row with no common on letter are significantly different $(\mathrm{P}<0.05)$.

during lactation (Evans and Mair, 213). Girard et al. (1995) found that the combined supplement of biotin and vitamin B12 increased milk production by 1.1 $\mathrm{kg} /$ day from 30.5 to $31.6 \mathrm{~kg} /$ day and milk protein yield from 1.04 to $1.07 \mathrm{~kg} /$ day without affecting dry matter intake. Graulet et al. (2007) found higher milk yield in early lactation with high levels of dietary folic acid, and speculated that the folic acid supplementation improved synthesis of purine and pyrimidine compounds in the mammary gland. Preynat et al. (2010) observed that the combined supplement of folic acid and vitamin B12 on lactation performance of dairy cows probably results from an improvement of energy metabolism during early lactation. Changes in plasma concentrations only reflect differences between the supply and tissue demands. In the experiment concerned, all cows received the same basal diet; hence, the nutrient supply should be similar among the treatments and differences in plasma concentrations are likely to reflect changes in tissue utilization. Evans and Mair (2013) suggested that a response can be anticipated at all levels of milk production. In cows fed supplementary folic acid, it seems that tissue utilization of biotin was increased by vitamin B12 supplementation and resulted in increased formation of protein. It is possible that dietary supplements of vitamins may have modified ruminal 
fermentations and the cows' nutrient supply. In this study milk fat tended to increase by B1 and B12 injection. Evans and Mair (2013) showed that milk fat on average increased when cows were given the B vitamin blend. Nonetheless, the results seem to indicate that supplemental vitamin B12 acts on the two vitamins B12 dependent metabolic pathways. Neither the interrelationships among the three B vitamins nor the effect that a suboptimal supply has on the major metabolic pathways are well understood (Girard and Matte, 2005). The mechanisms of action of dietary supplements of B vitamins should also be elucidated, in order to dissociate their effects on ruminal microflora and fermentation products from their direct effect on the cow post absorptive metabolism.

\section{Conclusion}

The results of the study indicated that milk protein was increased significantly in B1 and B2 treated groups while milk lactose decreased significantly in B1. Total protein increased significantly in B1 while cholesterol and triglyceride increased significantly in B12 in lactating cows.

\section{References}

Duncan DB (1955) Multiple range and Multiple Ftest. Biometrics 11:1.

Evans E, Mair DT (2013) Effects of a rumen protected B vitamin blend upon milk production and component yield in lactating dairy cows. Open $\mathrm{J}$ Anim Sci 3: 76-82.

Farahat ESA, Hanafy MA, Kholif AM, El-Shewy AA, Abdel Gawad MH (2007) Effect of supplementing ration with thiamin and/or sodium bicarbonate on ruminal fermentation, digestibility and serum parameters of rams. Egypt J Nutr Feed 10: 225-233.

Girard CL and Matte JJ (2005) Folic acid and vitamin B12 requirements of dairy cows: A concept to be revised. Livest Prod Sci 98: 123-133.

Girard CL, Matte JJ and Tremblay GF (1995) Gestation and lactation of dairy cows: A role for folic acid. J Dairy Sci 78: 404-411.
Graulet B, Matte JJ, Desrochers A, Doepel L, Palin MF, Girard CL (2007) Effects of dietary supplements of folic acid and vitamin B12 on metabolism of dairy cows in early lactation. $\mathrm{J}$ Dairy Sci 90: 3442-55.

Majee DN, Schwab EC, Bertics SJ, Seymour WM and Shaver RD (2003) Lactation performance by dairy cows fed supplemental biotin and a B-vitamin blend. J Dairy Sci 86: 2106-2112.

McDowell LR (2000) Vitamins in animal and human nutrition. Iowa State University Press, Ames, IA. 793.

National Research Council (2001) Nutrient Requirements of Dairy Cattle. $7^{\text {th }}$ rev ed Natl Acad Press, Washington DC.

Overton TR, LaCount DW, Cicela TM, Clark JH (1996) Evaluation of a ruminayl protected Methionine product for lactating dairy cows. J Dairy Sci 79: 631-638.

Preynat A, Lapierre H, Thivierge MC, Palin MF, Cardinault N, Matte JJ, Desrochers A, Girard CL (2010) Effects of supplementary folic acid and vitamin B 12 on hepatic metabolism of dairy cows according to methionine supply. J Dairy Sci 93: 2130-42.

SAS (2001) SAS User ś guide: Statistics, SAS Institute Inc, Cary, NC.

Sapienza DA (1981) A Hypothesis for the Etiology of Polioencephalomalacia. Ph.D. Dissertation. Kansas State Univ., Manhattan, KS, USA. Gray, R. W., and J. L. Na1416- 1420.

Solouma GMA, HA Hamdon and AM Kholif (2013) Effect of thiamin supplementation in ration on milk yield, composition and someblood components of Sohagi sheep. Egyp J Nutr Feeds 16: 17-25.

Solouma GM, Kholif AM, Hamdon HA, Aziz HA and El-Shewy AA (2014) Blood Components and Milk Production As Affected By Supplementing Ration with Thiamin In Ewe Sohagi Sheep. Life Sci J 11: 60-66.

Shaver RD and MA Bal (2000) Effect of dietary thiamin supplementation on milk production by dairy cows. J Dairy Sci 83: 2335-2340. 